\title{
STUDI EVALUASI PENCAHAYAAN ALAMI PADA GEDUNG \\ KULIAH BERSAMA III UNIVERSITAS MUHAMMADIYAH MALANG
}

\section{Ode Rapija Gw¹ ${ }^{1}$ Beta Suryo Kusumo}

Staf Pengajar Jurusan Teknik Sipil

Fakultas Teknik - Univ. Muhammadiyah Malan

Kampus III, Jl. Tlogomas No. 246 Telp. (0341) 464318-319 Pes. 130 Fax. (0341) 460435 e-mail: odewaibo@yahoo.com

Staf Pengajar Jurusan Teknik Arsitektur ${ }^{2}$

Fakultas Teknik - Universitas Brawijaya (Malang)

Email : Uyoke3@gmail.com

\section{ABSTRACT}

In Gedung Kuliah Bersama (GKB) III at University Muhammadiyah of Malang, at the first floor with a low-level of illumination should be used for audio-visual rooms or meeting, or it's no used to read, write a long time (often), and for a thorough job, so it does not require a high level of illumination, because the majority of rooms on the first floor level of 30 lux illumination only an the maximum light level is only about 300 lux at the window. On the second floor with office
the the maximum light level is only about 300 lux at the window. On the second floor with office
functions majors and computer labs are appropriate to the level of illumination most of the room functions majors and computer labs are appropriate to the level of illumination most of the room have a very high level of illumination, on the third floor reached 120-240 lux in the most of the have a very high level of illumination, on the third floor reached 120-240 lux in the most of the rooms and around the window to 1200 lux, the uneven illumination very disturbing visual comfor
of user room. On the fourth floor most of the rooms have lighting levels of 200-400 lux and 1800 of user room. On the fourth floor most of the

Key Words: Lighting levels or level of illumination, GKB ( Gedung Kuliah Bersama )

\section{PENDAHULUAN}

Pengembangan bangunan berlantai banyak telah menjadi kebutuhan akan ruang tempat beraktivitas manusia yang lebih efesien. Tuntutan ruang yang besar dan beragam di lahan sempit khususnya di kota-kota di Indonesia menjadi gejala umum. Keberadaan bangunan tinggi merupakan suatu fenomena yang tidak dapat dihindari dan intesitasnya cenderung semakin dihind in intesin meningkat dari tahun ke tahun. Didalam kerangka pemikiran akan dampak "global warming" dan menuju kawasan "green architecture", eksistensi figur bangunan tinggi ini mutlak harus diperhitungkan terutama dalam kapasitasnya sebagai pemakai energi yang potensial.

Pada suatu bangunan tinggi perkantoran yang tipikal, proporsi penggunaan energi umumnya meliputi $55 \%$ untuk sistim tata udara

50 |Media Teknik Sipil, Volume 9, Nomor 1, Februari 2011: 50 - 60 tersebut dalam konteks desain arsitektur bangunan tinggi (high rise building) yang meliputi green high rise dan bioclimatic high rise.

Pendekatan bioklimatik pada proses desain mempertimbangkan hubungan antara iklim dan kehidupan. Terutama pengaruh akibat iklim setempat terhadap kesehatan dan aktivitas manusia. Banyak elemen-elemen iklim yang merupakan faktor determinan dalam menghasilkan suatu rancangan bangunan antara lain temperatur udara, kelembaban, tekanan udara, curah hujan, intesitas dan lama penyinaran matahari, arah dan kecepatan angin. Indonesia merupakan iklim yang menganut tropis lembab. Pendekatan bioklimatik menekankan pada pemanfaatan potensi iklim setempat untuk mencapai kenyamanan fisik (termal dan visual) semaksimal mungkin dengan meminimalka penggunaan teknologi maupun peralatan yang menggunakan energi atau dikenal dengan metode pasif. Sistim pasif ini bisa dicapai dengan teknik desain arsitektur yang mengolah tatanan ruang, bidang, massa, dan elemen arsitektur. Pendekatan bioklimatik pada dasarnya bertitik tolak dari dua hal fundamental untuk menentukan strateg desain yang responsif terhadap lingkungan global yaitu kondisi kenyamanan manusia dan penggunaan energi secara pasif. Melihat profil penggunaan energi pada bangunan tinggi, strategi desain hemat energi perlu diprioritaskan denga mereduksi beban pendinginan untuk sistim tat udara dan meningkatkan penerangan alami untuk menggantikan sistim tata lampu terutama pada siang hari.

Meningkatkan penerangan alami untuk menggantikan sistim tata lampu (pada siang hari) dapat dijadikan model dalam perencanaan bangunan hemat energi. Dengan mengamati perilaku cahaya pada periode tertentu pada suatu bangunan akan dihasilkan kajian bentuk dan strategi pencahayan pada bangunan tersebut. Cahaya merupakan suatu unsur terpenting dalam penerangan dan penglihatan. Hasil karya manusia yang terwujud, misalnya berupa bangunan yang lainnya hampir tidak ada artinya tanpa adanya cahaya. Dipungkiri atau tidak karya arsitektur (bangunan) justru dapat dirasakan kehadirannya dengan adanya cahaya yang menyinari.

Ode Rapija Gw ${ }^{l}$, Beta Suryo Kusumo². Tingkat Pencahayaan Alami Pada Gedung Kuliah Bersama $\mid 51$ Iii Universitas Muhammadiyah Malang

Kehadiran cahaya pada lingkungan bertujuan menyinari berbagai bentuk elemen-elemen yans ada pada bangunan sehingga ruang menjadi teramati dengan jelas seakan terasakan suasana visualnya (visual sense). Selain itu kehadiran cahaya juga diharapkan dapat membantu pemakai ruang untuk dapat melakukan kegiatannya dengan baik dan terasa nyaman. Dalam pemenuhan atas fungsi dan kenyamanan dibutuhkan sumber cahaya yang berpengaruh pada ruang dan bangunan. Sumber cahaya dari alam atau disebut penerangan alami merupakan sumber cahaya yang dapat dimanfaatkan untuk penerangan. Pencahayaan alami berasal dari matahari yang dimasukkan kedalam bangunan melalu bukaan pada fasade bangunan.

Perancangan penerangan alami yang tepat adalah memasukkan radiasi matahari berupa cahaya pantulan kedalam ruangan dengan jumlah dan proporsi yang tepat dalam takaran kenyamanan secara visual. Cahaya dan terang alami merupakan prasyarat penting dalam penerangan alami. Cahaya terang sendiri dipengaruhi oleh bidang edar matahari sebagai sumber cahaya yang berdampak pada kondisi terang

Pada kubah langit, sistim penyinaran, karakter ruangan serta persepsi pemakai terhadap cahaya alami. Sebagai sumber cahaya, matahari, dan keberadaan matahari di Indonesia yang beriklim tropis sangat mempengaruhi bidang bukaan (jendela), Karakter ruang, bentuk bangunan dan tipologi bangunan. Di Indonesia yang menganut sistem iklim tropis lembab rancangan arsitektur khususnya bentuk bangunan dipengaruhi oleh konsep tropis lembab. Konsep pemahaman ini telah diyakini oleh para perancang bangunan tempo dulu.

Berdasarkan uraian diatas maka kajian strategis pada peningkatan sistim penerangan alamai juga dapat diterapkan pada bangunan publik seperti bangunan perkuliahan. Bangunan yang menarik untuk dikaji adalah bangunan GKB III Universitas Muhmili a dah ban dari empat lantai dengan pola ruangan yang sama dan sebagian besar difungsikan sebagai ruang kuliah. Berdasarkan pengamatan pada GKB III, 
kecenderungan penggunaan penerangan buatan pada ruang yang digunakan untuk beraktivitas menjadi hal rutin. Hal ini dikarenakan kemampaun penerangan alami pada saat tertentu tidak dapat memenuhi kemampauan penglihatan dalam ruang kerja. Penggunaan penerangan buatan juga tidak terlepas pada hal-hal yang melatarbelakangi keberadaan bangunan. Misalnya pada penataaan konfigurasi bangunan, pengaturan orientasi bangunan, perancangan fasade bangunan, pemanfaatan proteksi matahari, penggunaan landsekap vertikal dan vegetasi, penggunaan potensi ventilasi alamiah dan penentuan warna dan karakter.

Dalam kaitannya dengan peningkatan sistim penerangan alamiah pada ruang faktor tapak (konfigurasi bangunan), orientasi bangunan, perancangan fasade (bentuk bukaan/jendela), dan pemanfaatan proteksi matahari menjadi bagian dalam kajian.

Selain itu data-data cuaca yang akurat secara periodik merupakan faktor penting dalam engamati perilaku sistim penerangan alani tersebut. Berangkat dari kondisi ini dan fenomena pengamatan pada bangunan GKB III maka perlu dilakukan studi untuk mengetahui performans sistim penerangan alami pada peningkata penggunaanya pada ruang-ruang gedung GKB III.

\section{METODELOGI}

\section{Lokasi penelitian}

Kampus III Universitas Muhammadiyah Malang memiliki ciri tertentu untuk bangunanbangunannya. Bangunan kampus III Universitas Muhammadiyah Malang,umumnya menggunakan tap kombinasi pelana perisai, denah memanjang perna tih dan atapnya menggunakan genteng beton berwarna coklat

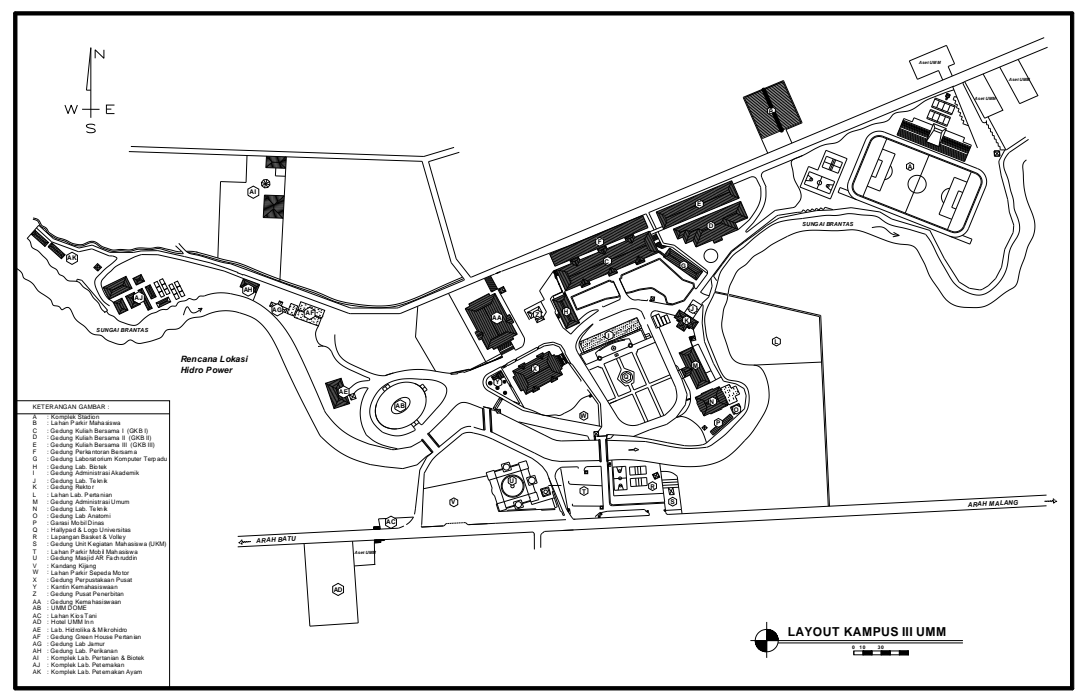

Gambar 1. Situasi Kampus III Universitas Muhammadiyah Malang Sumber: Dokumen UMM

52 |Media Teknik Sipil, Volume 9, Nomor 1, Februari 2011: 50 - 60

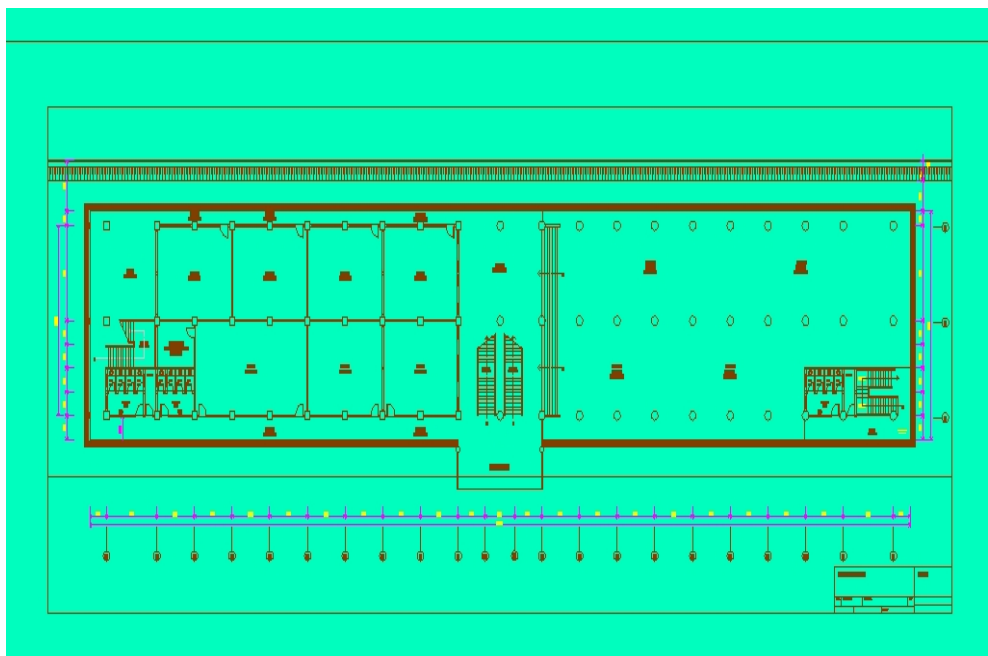

Gambar 2. Denah Gedung Kuliah Bersama III UMM Sumber: Dokumen BP3K-UMM

Deskripsi Iklim

langit. Adapun keadaan iklim dari kota Malang adalah sebagai berikut

Dalam kajian ini, keadaan iklim sangat mempengaruhi jumlah cahaya yang tersedia di

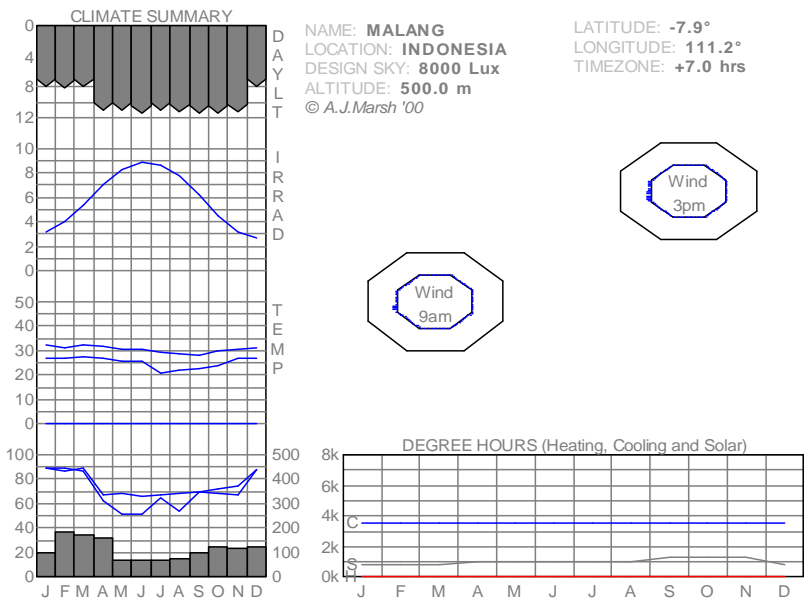

Gambar 3. Gambaran Umum Iklim Malang Sumber: Ecotech V520, Malang Dalam Angka

Ode Rapija Gw' ${ }^{l}$,Beta Suryo Kusumo². Tingkat Pencahayaan Alami Pada Gedung Kuliah Bersama $\mid \mathbf{5 3}$ Iii Universitas Muhammadiyah Malang 
Gedung GKB III UMM terletak di Kota Malang, yaitu di Jalan Raya Tlogomas. Malang secara geografis terletak pada $7,06^{\circ}-8,02^{\circ}$ Lintang Selatan dan $112,06^{\circ}-112,07^{\circ}$ Bujur Timur. Kota malang berhawa sejuk dan kering dengan kelembaban udara $72 \%$ serta suhu rata-rata $24,13^{\circ} \mathrm{c}$,
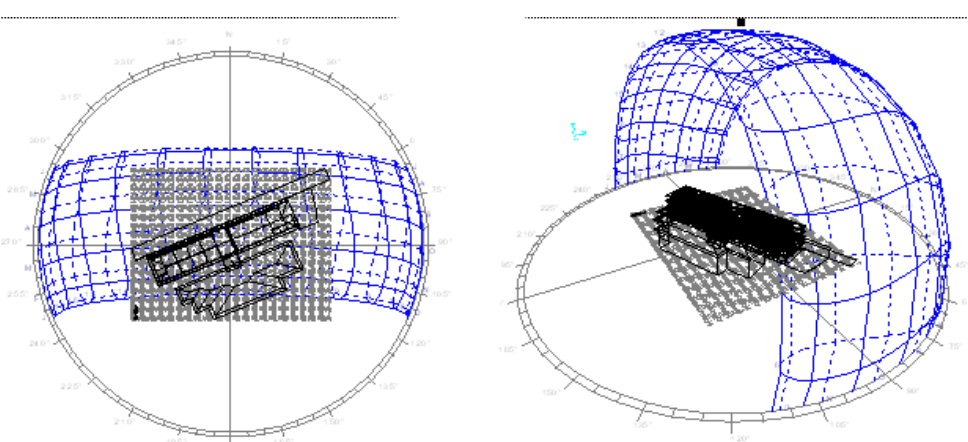

Gambar 4. Gedung GKB 3 dan Sun Path Diagramnya Sumber: Ecotech V520, Analis
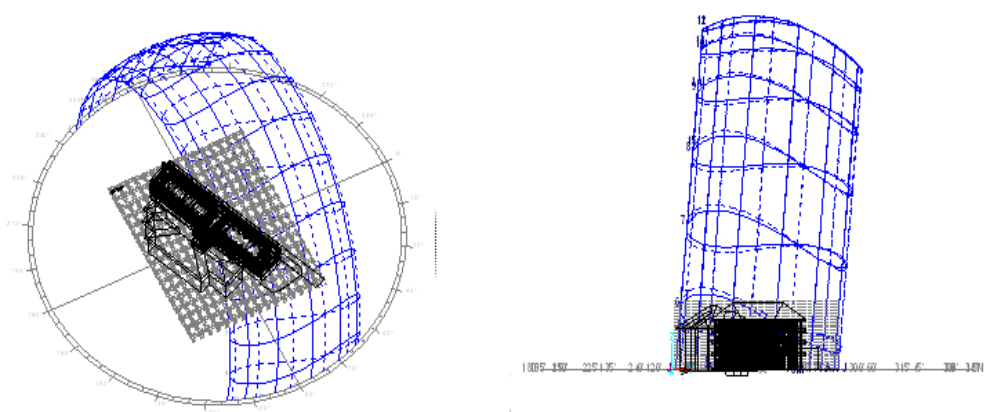

Gambar 5. Gedung GKB 3 Dilihat Dari Sun Position Sumber: Ecotech V520, Analisa

54 |Media Teknik Sipil, Volume 9, Nomor 1, Februari 2011: 50 - 60

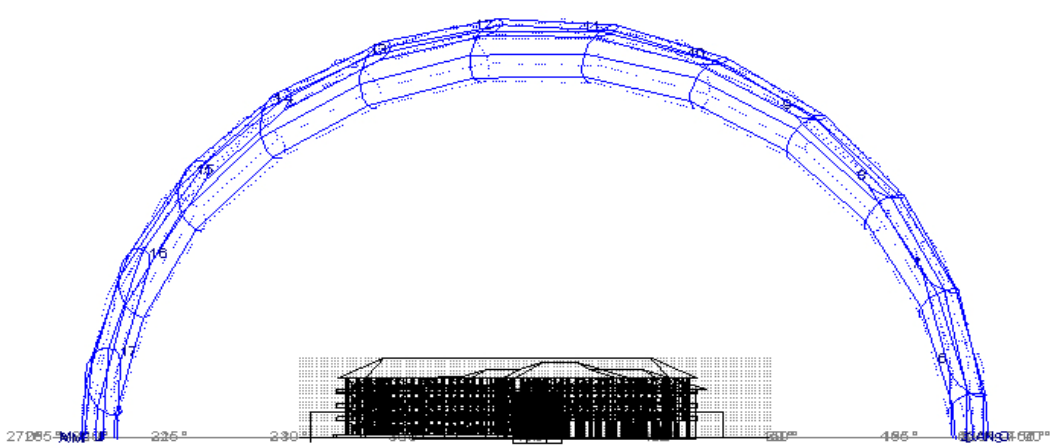

Gambar 6. Gedung GKB 3 Dilihat Dari Tampak Samping Barat Dan Utara Sumber: Ecotech V520, Analisa

Pada pengujian ini beberapa poin penting yang HASIL DAN PEMBAHASAN perlu diketahui dalam pemilihan kondisi yang digunakan adalah sebagai berikut.

Analisa dalam Software Ecotech v.520 adala menggunakan full-daylight analysis only

\section{Tingkat Pencahayaan Pada Lantai Satu}

b. Presisi yang digunakan adalah high da keadaan kacanya menggunakan rata-rata (average cleanness)

c. Keadaan langit yang digunakan adalah overcast

d. Design sky illuminance/penerangan lang dasar yang digunakan adalah sebesar 10000 lux. Dalam analisis ini nilai yang digunakan merupakan optional/tidak mengikat dan hanya berpengaruh pada nilai penerangan yang berasal dari daylightfactor. Nilai ini mewakili tingkat cahaya yang muncul lebihdari $85 \%$ dar pukul 9 pagi sampai pukul 5 sore.

Pada lantai satu tidak mendapatkan cahaya matahari langsung sepanjang hari, Lantai satu terhalang gedung kuliah bersama II dan tembok pagar yang menutupi bidang sinar penerangan alami yang masuk. Dampaknya tingkat penurunan kualitas cahaya cenderung menurun tajam, pencatatan pada beberapa titik amatan dengan lux meter di lantai satu seperti pada ruang rapat fakultas tingkat pencahayaan sebesar 50 lux dibidang kerja dekat jendela dengan membuka tirai. Kondisi ini mengakibatkan penggunaan penerangan buatan menjadi bagian rutin. Pada pengamatan dilakukan Sedangkan dengan analisa ecotech 520 pada ruang rapat fakultas tingkat pencahayaan mencapai 48,16 lux seperti terlihat pada Gambar

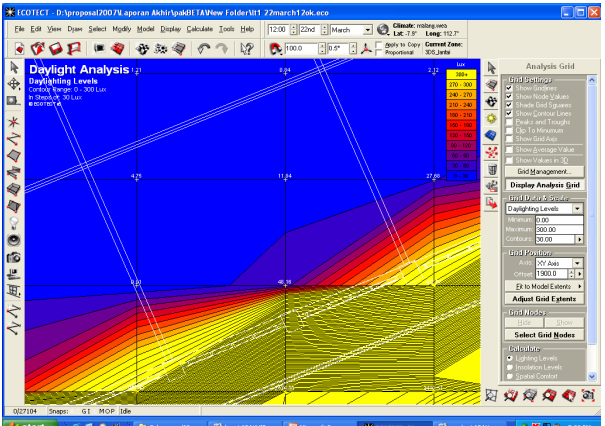

Gambar 7. Tingkat Pencahayaan Pada Ruang Rapat Fakultas Teknil Sumber: Analisa Ecotech V.520

Ode Rapija Gw $w^{l}$ Beta Suryo Kusumo². Tingkat Pencahayaan Alami Pada Gedung Kuliah Bersama $\mid \mathbf{5 5}$ Iii Universitas Muhammadivah Malang 
Pengukuran pada ruang baca dan perpustakaan mencapai nilai 20 lux. Hasil analisa dengan ecotech fakultas teknik, tercatat sebesar 300 lux bila 520 tingkat pencahayaan sebesar 27,68 lux, liha menggunakan penerangan buatan. Pada kondisi gambar 8. Perbedaan terjadi pada teras fakultas, lampu dimatikan tingkat pencahayaan turun tingkat pencahayaan sebesar 300 lux.

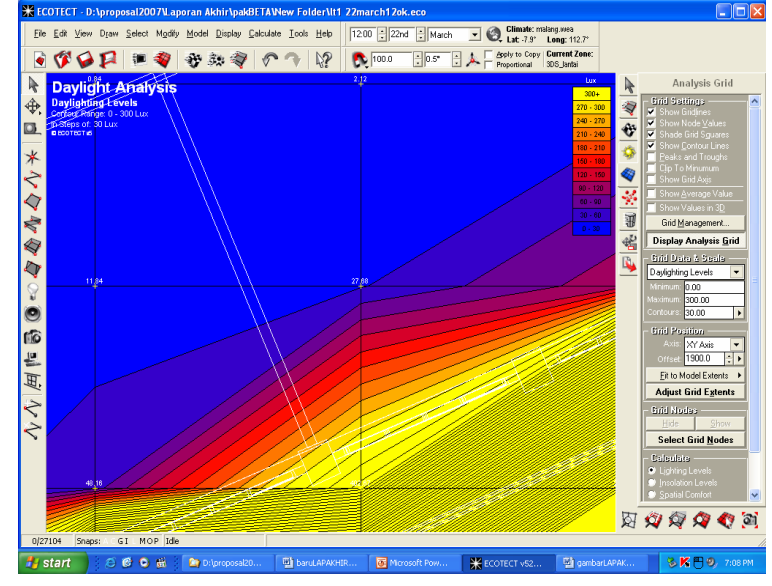

Gambar 8. Tingkat Pencahayaan Pada Ruang Baca Dan Perpustakaan Fakultas Teknik Sumber: Analisa Ecotech V.520

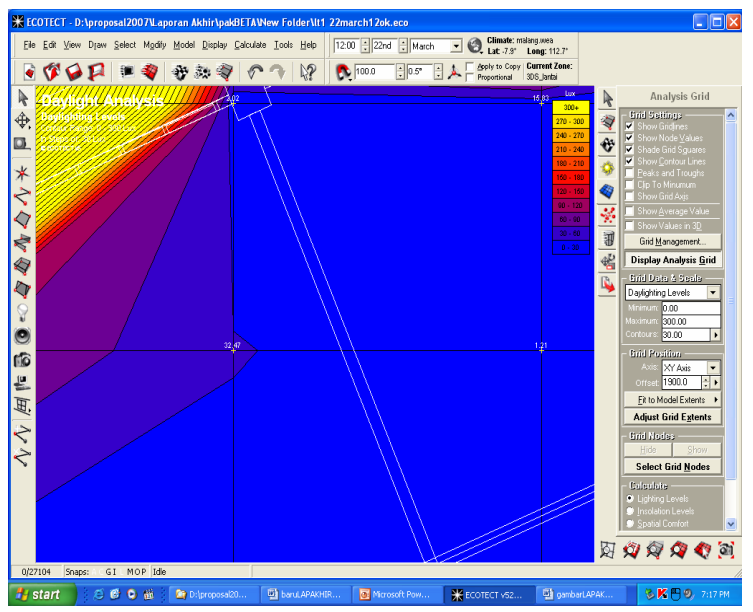

Gambar 9. Tingkat Pencahayaan Pada Ruang Transit Sumber: Analisa Ecotech V.520

Pengukuran berikut pada ruang transit yang Di dekat jendela dengan tirai terbuka sebesar 150 erletak di lantai satu, di bidang kerja tingkat lux. Ruang kerja pembantu dekan tiga dalam pencahayaan sebesar 30 lux, dan hasil analisa kondisi lampu tidak dinyalakan dan korden dibuka ecotech 520 tingkat pencahayaan sebesar 32,47 lux.

56 |Media Teknik Sipil, Volume 9, Nomor 1, Februari 2011: 50 - 60

tingkat pencahayaan yang tercatat hanya sebesar 50 lux saja.

\section{Tingkat Pencahayaan Pada Lantai Dua}

Berdasarkan hasil penukuran dengan lux mete pada ruang ruang kerja dilantai dua pada daera yang mendekati tengah ruang kerja seperti pada ruang kantor laboratorim autocad tercatat tingkat

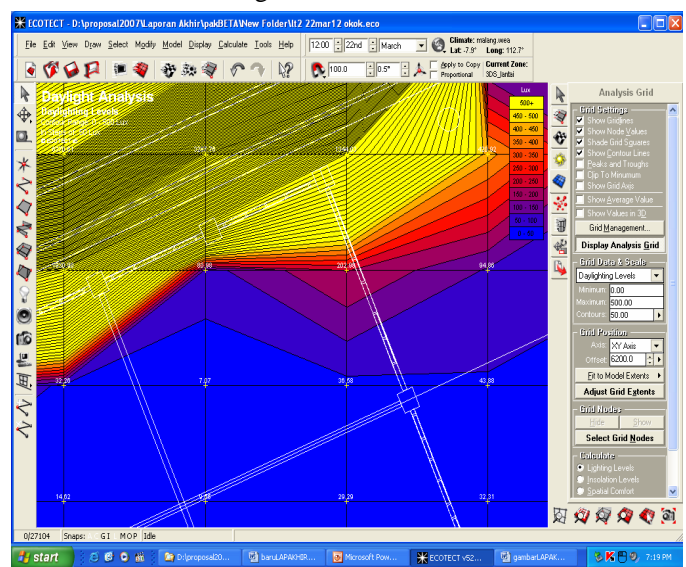

Gambar 10. Tingkat Pencahayaan Pada Ruang Kantor Jurusan Teknik Sipil Sumber: Analisa Ecotech V.520

Tingkat Pencahayaan Pada Lantai Tiga

Berdasarkan data lapangan yang diukur dengan luxmeter pada ruang kelas 316 yang terletak pada lantai tiga tercatat tingkat pencahayaan sebesa 1100 lux, dan semakin besar pada daerah dekat jendela. Hal ini relative sama dengan hasil analisa Ecotech v.520, dimana cahaya yang masuk ke dalam ru terlihat pada gambar 11

Akibatnya beda tingkat pencahayaan yang besar antara minimum dan maksimum dalam ruang maka terjadi silau, sehingga cenderungan menggunakan korden. Penggunaan korden memperburuk kualitas penerangan, Olehkarena itu, perlu penggunaan bidang proteksi atau shading device yang berguna menyaring cahaya matahar langsung yang masuk kedalam ruang, dengan

Ode Rapija Gw $w^{l}$.Beta Suryo Kusumo². Tingkat Pencahayaan Alami Pada Gedung Kuliah Bersama $\mid \mathbf{5 7}$ Iii Universitas Muhammadiyah Malang tean pada level 230 lux tingkat pencahayaan menjadi besar pada daerah dekat jendela. Pada ruang kantor jurusan teknik sipil nilai tingkat pencahayaannya sebesar 200 lux. Hal ini seperti terlihat pada gambar 8 , dengan menggunakan analisa ecotech 520,diperoleh tingkat pencahayaan sebesar 202,98 lux pada kantor jurusan teknik sipil

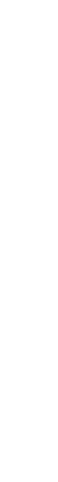

menyebarkan terang/cahaya tersebut menjadi baur dan mengkondisikan shading device tersebut hingga tingkat pencahayaan yang masuk pada level
350 sampai dengan 500 lux. Efek samping dari cahaya matahari langsung adalah peningkatan suhu dalam ruang, akibatnya ruang terasa panas 


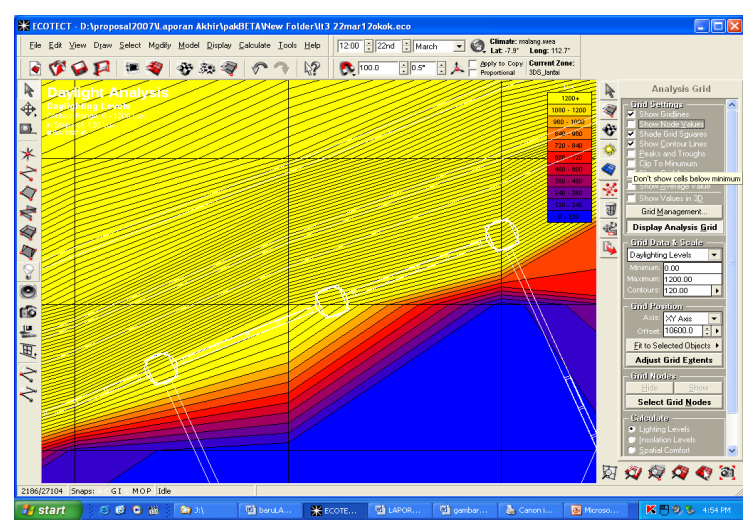

Gambar 11. Tingkat Pencahayaan Pada Ruang Kelas 316 Lantai Tiga Sumber: Analisa Ecotech V.520

Tingkat Pencahayaan Pada Lantai Empat

lux pada kondisi tidak mendapat sinar matahar langsung. Hal ini terjadi akibat tidak ada

Pada pengukuran lantai empat kualitas penghalang pada terang langit yang masuk, penerangan melonjak drastis pada rung bersama sehingga diperlukan shading device untuk atau auditorium. Akibat tidak adanya halangan menurunkan tingkat pencahayaan yang tinggi disekitar seperti rendahnya ketinggian pohon dan tersebut. Penggunaan shading device berfungs ruang yang terbuka menyebabkan tingkat ganda adalah mengurangi laju aliran hawa pana pencahayaan maksimal dalam ruang mencapai 1800 dan membuat bidang baur atas cahaya yang datang lux, seperti terlihat pada gambar 12. Pengukuran dengan penyesuaian desain agar rasio kecukupan dengan lux meter tingkat pencahayaan pada selasar tingkat pencahayaan alami dalam ruang berkisa atau pada ruang tunggu di lantai empat sebesar 2700 pada 500 lux

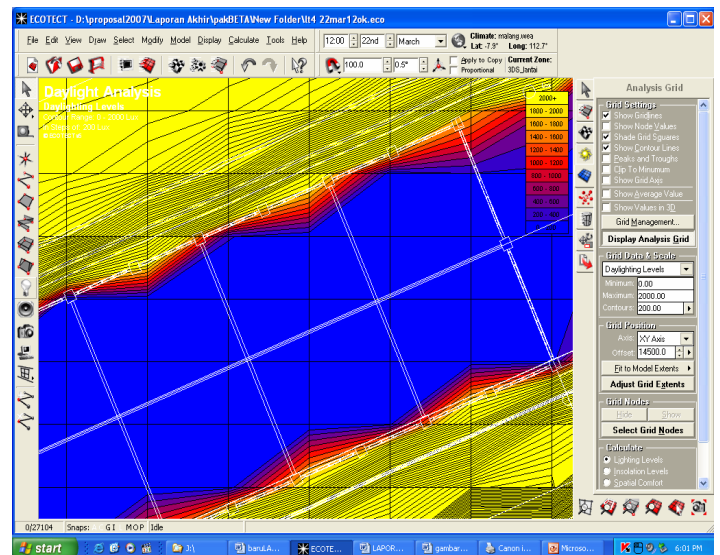

Gambar 12. Tingkat Pencahayaan Pada Ruang Kelas 401 Lantai Empat Sumber: Analisa Ecotech V.520

\section{KESIMPULAN}

Dari hasil penelitian di lapangan dan pengujian model simulasi terhadap penerangan alami pada gedung kuliah bersama III Universita Muhammadiyah Malang, dapat disimpulkan sebagai berikut :

a. Lantai satu dengan tingkat pencahayaan yang rendah sebaiknya digunakan untuk ruangruang audio visual atau rapat, atau yang tidak digunakan untuk membaca dan menulis lama (sering) serta teliti, sehingga tidak memerlukan tingkat pencahayaan yang tinggi, karena pada sebagian besar ruang di lantai satu tingkat pencahayaan hanya sebesar 30 lux dan tingkat pencahayaan maksimum hanya sekitar 300 lux di dekat jendela.

b. Penataan ruang pada masing-masing unit kegiatan yang beberapa menempati ruang dalam ruang, sehingga cakupan penerangan alami sangat rendah. Hal ini terlihat dari penggunaan penerangan buatan sepanjang har pada lantai satu.

c. Pada lantai dua dengan fungsi perkantoran jurusan serta laboratorium komputer sudah tepat dengan tingkat pencahayaan sebagian besar ruang mencapai 200 lux, di dekat jendela tingkat pencahayaan maksimum mencapai 500 lux.

d. Ruang kuliah pada lantai 3 dan 4 mempunya tingkat pencahayaan yang sangat tinggi, pada lantai tiga mencapai 120-240 lux di sebagian besar ruang dan di sekitar jendela mencapai 1200 lux, penerangan yang tidak merata sangat menggangu kenyamanan visual pemakai ruang. Pada lantai empat sebagaian besar ruang memiliki tingkat pencahayaan sebesar 200-400 lux dan mencapai maksimum 1800 lux di sekitar jendela.

\section{DAFTAR PUSTAKA}

Bockott, HE, GodFrey, JA (1974), Window, Performance, Design, And Installation, Van Nostrand Reinhold, New York.
Brown, G.Z. (1987) Sun, Wind, and Light, Alih Bahasa Aris K.O, Intermatra, Bandung.

Brown, G.Z. \& Mark DeKay (2001), Sun, Wind and Light, Architectural Design Strategies. John Wiley and Sons.

Djunaedi, Achmad (1989). Pengantar Metodologi Penelitian Arsitektural. Jurusan Teknik Arsitektur Fakultas Teknik. Universitas Gajah Mada Yogyakarta

Egan, DM., (1983), Concepts in Architectural Lighting Mc Graw Hill Books Company, New York.

Evan, B.H: Daylight in Architechture Architectural Record Books Mc. Graw-Hill Book Company, New York,

Hopkinson, RG; Kay, JD. (1968) The Lighting of Building, , Fabor, London.

http://www.archlighting.com architecturallighting/images/pdf/ Lincoln_Web.pdf

http://www.light-creation.co.jp/Architectural-1e.html

Juwana, Jimmy S. (2005). Panduan Bangunan Ting gi UntukArsitek dan Praktisi Bangunan. Jakarta: Penerbit Erlangga.

Koenigsberger, Ingersoll, Mayhew, Szokolay (1973), Manual of Tropical Housing and Building, Part 1. Climatic Design. Longman Group

Lam, William M.C (1977), Perception and Lighting as Formgivers for Architecture. Van Nostrad Reinhold : NewYork.

Lam, William M.C (1986), Sunlight as Formgivers for Architecture. McGraw-Hill.

Mangunwijaya, YB (2000), Pengantar Fisika Bangunan. Penerbit Djambatan, Jakarta.

Ode Rapija Gw', Beta Suryo Kusumo². Tingkat Pencahayaan Alami Pada Gedung Kuliah Bersama $\mid 59$ Iii Universitas Muhammadiyah Malang 
Nazir, Moh. Ph.d. (1988). Metode Penelitian. Jakarta: Penerbit Ghalia Indonesia.

Santosa, M (1985) Building Science And Architectureal Science, Department of Architecture, Faculty of Civil Engineering and Planning, Sepuluh Nopember Institute of Technology, Surabaya.

Seminar Studi Kemungkinan Transformasi Konsep Richard Meier Ke Dalam Arsitektur Tropis Indonesia

Serial Rumah.2005. Lighting-Percantik Interior \& Eksterior. Jakarta : PT Prima Infosarana Media.

SP Honggowidjaja (2000), Jurnal Pengaruh Signifikansi Tata Cahaya pada Desain Interior, Staf Pengajar Fakultas Seni dan Desain, Jurusan Desain Interior Universitas Kristen Petra Surabaya.

Wilkes, Joseph A (1988). Envelopes, Building. Encyclopedia of Architecture: Design, Engineering \& Construction. Vol.2. Jon Wiley Son.

Wilkes, Joseph A. (1988). Atrium Buildings. Encyclopedia of Architecture: Design, Engineering \& Construction. Vol.1. Wiley.

Wilkes, Joseph A. (1988). Lighting-daylighting. Encyclopedia of Architecture: Design, Engineering \& Construction. Vol.3. 